\title{
"CHAINED BY HER DESTINY" - THE GRAVE OF A FEMALE WITH A TODDLER AT THE LA TÈNE CEMETERY IN NITRA-MLYNÁRCE ${ }^{1}$
}

\author{
Jozef Bujna
}

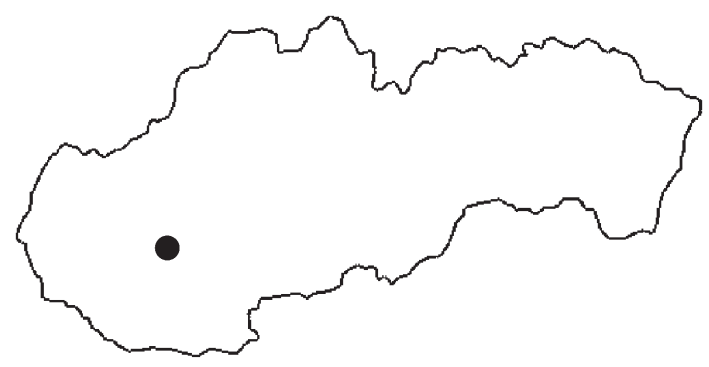

DOI: https://doi.org/10.31577/szausav.2019.65.4

Key words: grave of a female with a toddler, cemetery, Middle La Tène period, Nitra region, southwest Slovakia

The article pays attention to a specific inhumation grave of a female with a toddler uncovered together with $10 \mathrm{cre}-$ mation graves from the Middle La Tène period (stage LTC1) at the site of Nitra-Mlynárce. The inhumation grave is dated to the end of stage LTC1 $(\mathrm{C} 1 \mathrm{~b}-\mathrm{c})$ and it can be characterized by several specific attributes: 1 rare orientation of the buried woman with her head to the east; 2 depositing of remains of the dead female in a flexed ("hocker") position on the right side which can be associated with the baby in her arms; 3 specific costume garniture characterized by absence of anklets, by a chain belt and an armlet; 4 higher social status of the buried female indicated by textiles/ burial shroud decorated with gold; 5 chain of 23 mutually hooked cramp irons probably as a symbol of the kinship of the mother and her child. The remarkable grave complex is assessed in the context of analogous finds and palaeodemographic profile.

The literary title "Chained by her destiny" hides a fatal story of a woman buried together with a toddler at a La Tène cemetery in Nitra-Mlynárce. Her life story ended by death apparently not long after she had given birth to her baby. The mode of her burial as well as grave goods suggest that it was an unusual burial.

\section{FIND CONTEXT}

We know about 90 sites with grave finds from the La Tène period in the southern territory of western Slovakia and approx. 800 graves altogether (for more details see Repka 2014). In the Middle La Tène period, a distinct settlement concentration was created between the Váh and Ipel' rivers (Repka 2014, 32, fig. 2). In its northern part, the territory of the town of Nitra is situated (area of approx. $100 \mathrm{~km}^{2}$ ), from where 7 sites with grave finds from the La Tène period are known, one is questionable and the ninth one is just next to the town's territory (Fig. 1; Březinová 1999, 66-69, fig. 4; tab. 2). In total, there are approx. 30 graves.

The cemetery with the studied grave of a female buried with a toddler was situated in Mlynárce, the part of the town Nitra on a low terrace of the Nitra river's right bank. Ninety burials of the Lusatian culture including 11 burials from the La Tène period were uncovered over an area of $50 \times 150 \mathrm{~m}$ by rescue excavations in 1972 during construction of an overpass (Bujna 1992). The 11 uncovered graves from the La Tène period included 10 cremation graves and one inhumation. ${ }^{2}$

A female of approx. 35-40 with a 7-8-month-old child was buried in inhumation grave 9. ${ }^{3}$ The context is indicated as $9 \mathrm{~A}$.

1 This study was supported by research project 1/0680/16 of the Scientific Grant Agency VEGA of the Slovak Republic.

2 I would like to extend my thanks to the Directory Board of the Institute of Archaeology of the Slovak Academy of Sciences in Nitra for the opportunity to publish the La Tène burial complex from the site of Nitra-Mlynárce.

3 The anthropological estimation of age was provided by RNDr. J. Jakab, CSc. from the Institute of Archaeology of SAS in Nitra, for which I would like to express my thanks. 


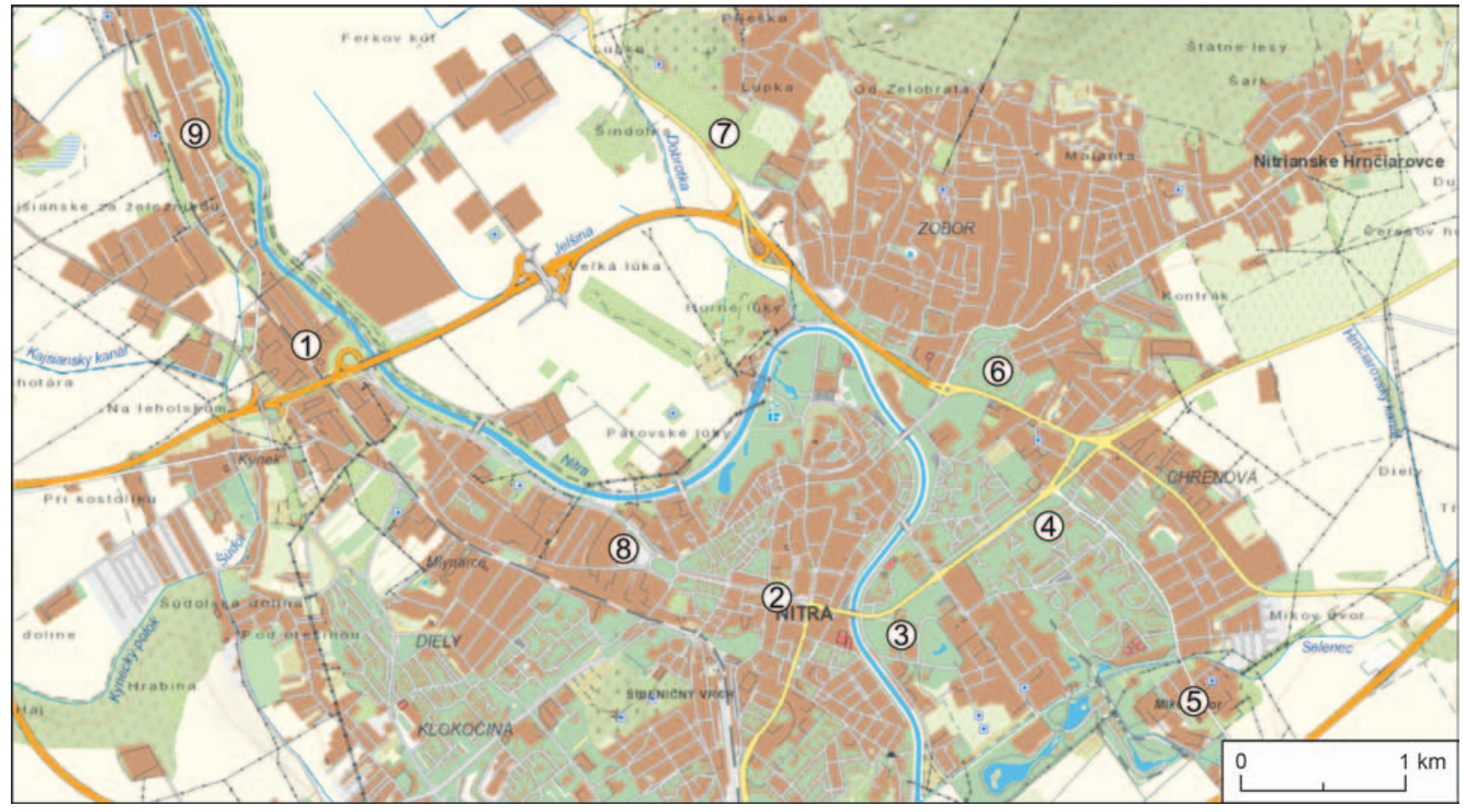

Fig. 1. Sites with grave goods from the La Tène period in the territory of the town of Nitra. 1 - Nitra-Mlynárce (Bujna 1992); 2 - Nitra, Štúrova ulica, Regional Court, previously Námestie 1. mája square (Paulík/Novotná/Benadik 1962, 320, Fig. 58; Pieta 1993); 3 - Nitra, Slovenská pol’nohospodárska univerzita - SPU (Slovak University of Agriculture), previously Vysoká škola pol’nohospodárska - VŠP (Lichardus 1964); 4 - Nitra-Chrenová II (Pieta 1993, fig. 8: 2, 3); 5 - Nitra-Mikov dvor (Bujna/Kováčová 1988); 6 - Nitra-Zobor, Matinský vrch (Chropovský 1986); 7 - Nitra-Zobor, Šindolka (Chropovskýl Kováčová/Csásta 1989); 8 - Nitra, Hypermarket Tesco (?; Bujna/Štefanka 2001); 9 - Lužianky (Eisner 1933, 170-176).

\section{Context 9A}

The shape and size of the grave pit were not detected by the rescue excavations during the earthworks related to the construction of the overpass. The female body deposited on the right side in a flexed ("hocker") position and approx. east (head) - west oriented was uncovered $90 \mathrm{~cm}$ deep. A toddler was placed in the woman's arms. The child's skeleton was strongly decayed (Fig. 2; 3). ${ }^{4}$

Several pieces of spirals made of gold wire (1) were found scattered around the female and child bodies, an iron fibula (2) was placed on the chest, an iron chain belt with a bronze fibula secondarily used as a belt hook (3) was placed around the waist and a chain of cramp irons (4) was found under the trunk and along the back.

1. Gold wire spirals. Several pieces of small spirals made of a very fine gold wire multiply twisted into an oval spiral. Only two pieces were successfully picked up, diameter of $4-6 \mathrm{~mm}$, weight of $0.45 \mathrm{~g}$ (Pl. I: $1 a, b)$.

2. An iron fibula. A wire fibula, rather long biconically moulded foot, preserved in fragments, foot $36 \mathrm{~mm}$ long, spring diameter of $6 \mathrm{~mm}$, external cord (Pl. I: 2).

3a. A bronze Certosa type fibula, without spring, $55 \mathrm{~mm}$ long. Used as a belt hook. An iron circular link inserted instead of a spring in the eye on the end of the bow, a link from an iron chain belt attached to the foot button by corrosion (Pl. I: 3a).

3b. An iron chain belt. Chain belt made from iron figure-of- 8 links, link length of approx. $35 \mathrm{~mm}$ with central moulding, diameter of approx. $7 \mathrm{~mm}$, connected by iron ring links, diameter of approx. $10 \mathrm{~mm}$; preserved length approx. $350 \mathrm{~mm}$ (Pl. I: 3b).

4. A chain of cramp irons. Chain of 23 hooked cramp irons. Cramp irons in shape of flat bars, approx. $2 \mathrm{~mm}$, narrowed towards the bent ends, max. width of 7-15 $\mathrm{mm}$, some exemplars slightly bent, with various lengths of approx. 90-200 mm (Pl. I: 4a-k; II).

4 Plan of grave 9 in a digital form was created by Mgr. M. Styk, PhD from the Department of Archaeology of the Faculty of Arts of the Constantine the Philosopher University in Nitra, to whom I would like to express my thanks. 

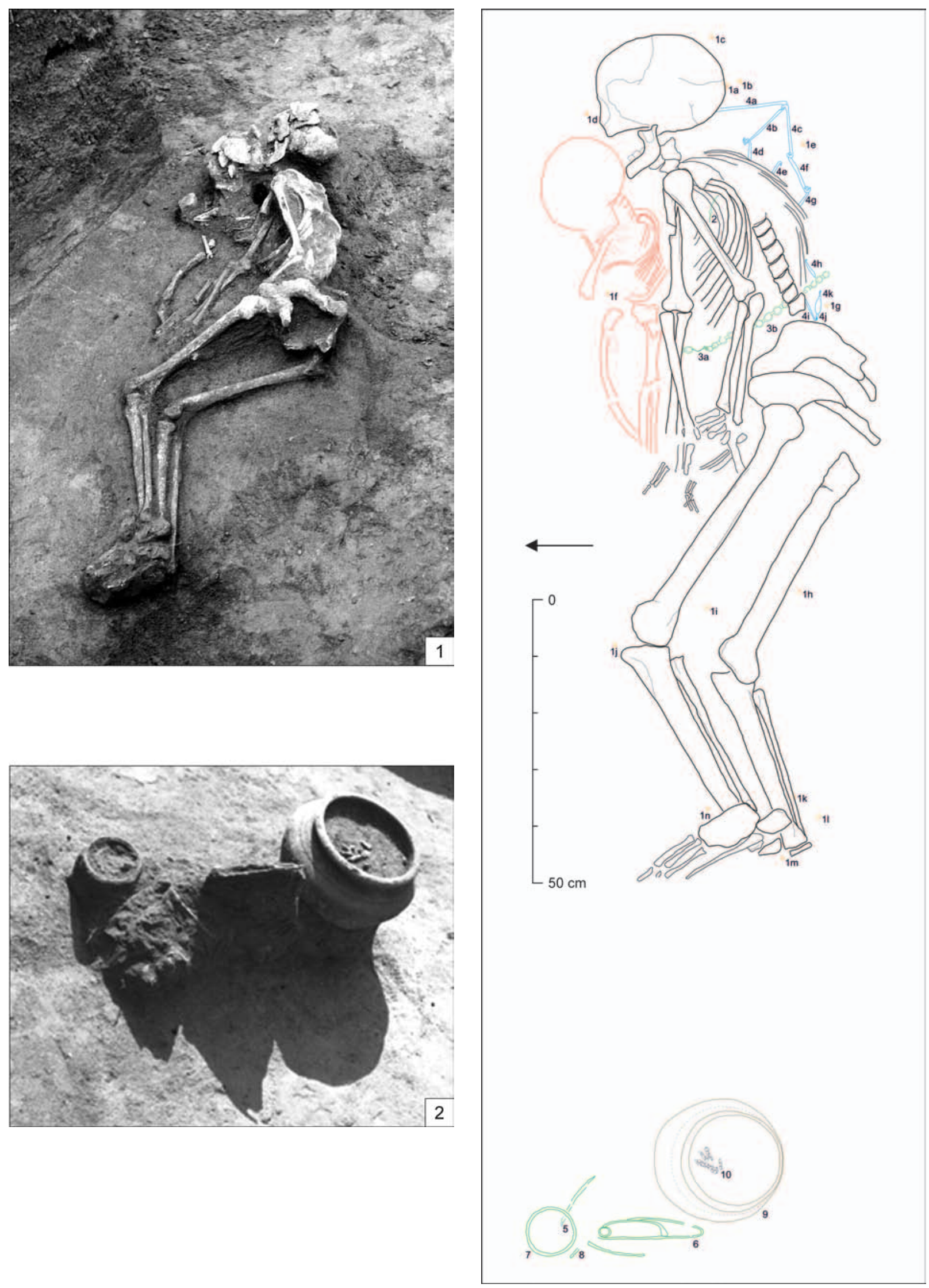

Fig. 2. Nitra-Mlynárce, grave 9. 1 - context 9A; 2 - context 9B. Photo source Archive of the Institute of Archaeology of SAS Nitra.

Fig. 3. Nitra-Mlynárce, grave 9, contexts 9A and 9B. 


\section{Context 9B}

Approx. $40 \mathrm{~cm}$ west of the female's feet and 80-90 cm deep, bones from a swine cranium (10) and a vessel (9) under them were uncovered. Next to the vessel, there was a bronze fibula (5), an iron fibula (6), an iron ring (7) and a fragment of a bronze bar (8).

5. A bronze fibula with the foot decorated by a quadratic boss and strapped to a frameshaped bow, spring $2+2$, diameter of $6 \mathrm{~mm}$, internal cord, total length of $42 \mathrm{~mm}$ (Pl. III: 1).

6. An iron fibula with a moulded foot strapped to a frame-shaped bow, spring $2+2$, diameter of $11 \mathrm{~mm}$, with external cord, total length of 142 mm (Pl. III: 2).

7. An iron ring, partly preserved plastic, slightly moulded decoration, inner diameter of $78 \mathrm{~mm}$, outer diameter of $85 \mathrm{~mm}$ (Pl. III: 3).

8. A fragment of a bronze bar, $33 \mathrm{~mm}$ long, diameter of $3 \mathrm{~mm}$, probably from a bracelet (Pl. III: 4).

9. A vessel on a short base, with a short neck separated from high shoulders by a distinct cordon like the conical body from the ringshaped base, $235 \mathrm{~mm}$ tall, max. diameter of $220 \mathrm{~mm}$; material with admixture of graphite (Pl. III: 5; Fig. 4).

10. Bones from a swine cranium.

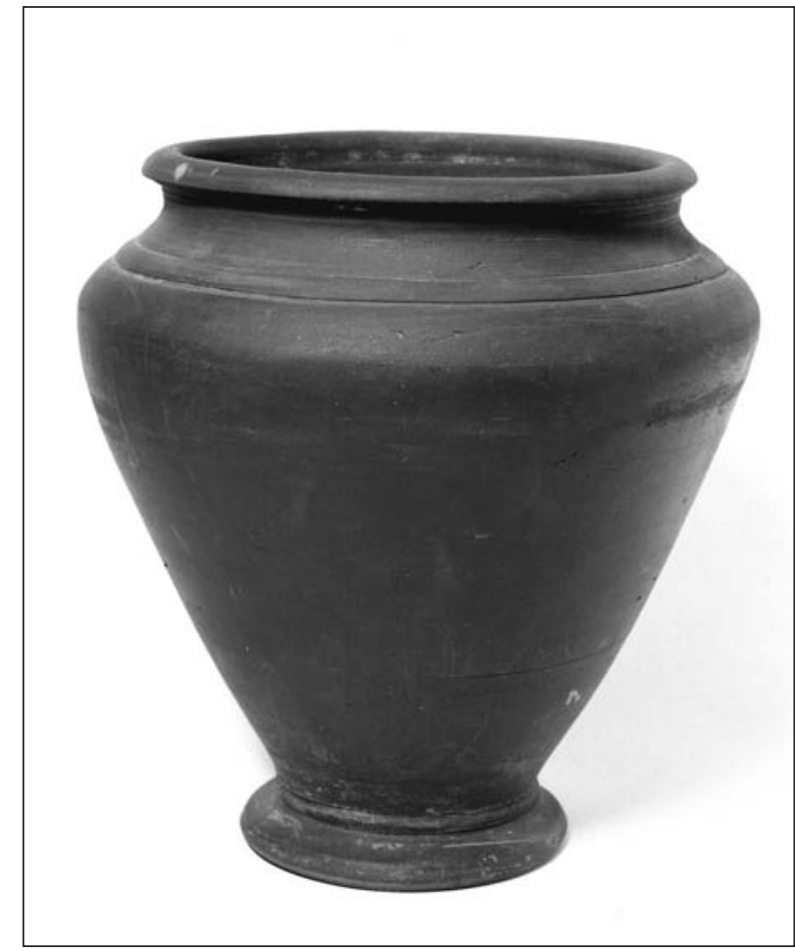

Fig. 4. Nitra-Mlynárce, grave 9, context B. Vessel. Photo source Archive of the Institute of Archaeology of SAS.

\section{FINDS AND THEIR ASSESSMENT}

Context 9A can be dated to the end of stage of stage LTC1 $(\mathrm{C} 1 \mathrm{~b}-\mathrm{c})$ on the basis of the iron fibula (find 2) of probably EF-Lx-A type (Bujna 2003, 81, fig. 60) and mainly of the iron belt chain (find 3b) of Gk-D-B type (Bujna 2011, 83-86, fig. 35; tab. 55). Context 9B also belongs to the final phase of stage LTC1, according to the find of the bronze fibula (find 5) of BF-Hy1-B type (Bujna 2003, 59, 60, fig. 26), the iron fibula (find 6) of EF-K-A type (Bujna 2003, 81, fig. 61) and probably also the iron ring (find 7) of ER-B2 type (Bujna 2005, 102, fig. 83).

The spatial relation of contexts $9 \mathrm{~A}$ and $9 \mathrm{~B}$ - with regard to absence of their groundplans - cannot be clearly defined. Since no bones of another human individual were found in the area of context $9 \mathrm{~B}$ and according to the relative chronology, both contexts were probably contemporary and very close (approx. $40 \mathrm{~cm}$ from each other), contexts 9A and 9B were probably parts of one whole, i. e. one grave. If so, the bronze and iron fibulae as well as the iron and probably also the bronze rings (finds 5-8) deposited next to the female's body apparently for ritual reasons were parts of her personal goods. A similar situation has been documented e. g. in inhumation grave 38 at the La Tène cemetery in Mannersdorf am Leithagebirge in Lower Austria, where vessels were deposited next to the legs of the buried female together with five bronze fibulae and two bronze rings (Ramsl 2011, 48f., fig. 31; 32; tab. 68).

The chain belt of figure-of- 8 links with central moulding and ring-links is frequent in the territory of Central Europe and the Carpathian Basin (Rustoiu 2008, 18 f., fig. 4). The monometalic form whose figure-of-8 links and central moulding are made of iron - Gk-D-B type (Bujna 2011, 83-86, fig. 35) occurs in stage LTC1 as part of female costume. This type of chain belts made of figure-of- 8 links is known from the territory of southwestern Slovakia from 4 burial complexes with female goods. All four complexes belong to phases LTC1b-c. This type of chain belt is frequently documented from the cemetery in Ižkovce in eastern Slovakia (Bujna 2011, tab. 55). 
Tab. 1. La Tène graves with golden objects in the grave goods from the territory of Slovakia and from the cemetery Mannersdorf am Leithagebirge (Lower Austria). F - Female; M - Male; Inf. - Child. Mannersdorf am Leithagebirge: graves 10/17 - LTB1b; 13/20a, 13/20b - LTB1a; 22/3b - LTB1b; 86/1, 86/2 - LTB1b; 115/7, 115/8 - LTB1c (Ramsl 2011, 237, 238).

\begin{tabular}{|c|c|c|c|c|c|}
\hline Cemetery & Grave & $\begin{array}{c}\text { Genderl } \\
\text { Age }\end{array}$ & Gold object & Dating LT & Literature \\
\hline Dubník & 19 & M mat. II & annular finger-ring & B1/B2 & $\begin{array}{l}\text { Bujna 1989, 268, fig. 24, pl. XX: 4; } \\
\text { Jakab/Vondráková 1989, } 357 \text { f. }\end{array}$ \\
\hline Galanta-Nebojsa & 5 & $\mathrm{~F}$ & annular finger-ring & B1c & $\begin{array}{l}\text { Chropovský 1958, 123-125, fig. 3, } \\
\text { pl. III: } 12 .\end{array}$ \\
\hline Hurbanovo-Bacherov majer & 11 & F mat. & annular saddled finger-ring & B1b & $\begin{array}{l}\text { Benadik/Vlček/Ambros 1957, 66, 70, 71, } \\
\text { pl. XXV: 4; VIček 1957, } 238 .\end{array}$ \\
\hline Maňa & 119 & $F(?)$ & annular saddled finger-ring & $\mathrm{B} 1(?)$ & $\begin{array}{l}\text { Benadik 1983, } 53 \text { f., pl. XLII: 16; } \\
\text { Dacík 1983, } 155 .\end{array}$ \\
\hline Palárikovo & 75 & Inf. & annular saddled finger-ring & B1c & Benadik 1975, 98, fig. 7, 8. \\
\hline Mannersdorf am Leithagebirge & 5 & $\mathrm{~F}$ & 5 finger-rings, 3 bracelets & B1a-c & Ramsl 2011, 237, 238. \\
\hline
\end{tabular}

Use of an antique Certosa type fibula as a belt hook is a peculiarity of the chain belt from burial 9 at the cemetery in Nitra-Mlynárce. An iron link is now inserted in the eye on the end of the bow, where its spring was originally inserted; a fragment of an iron link from the chain belt is attached by corrosion to the ball-shaped foot end of the fibula (Pl. I: 3a).

An almost completely preserved chain belt of figure-of- 8 links comes from grave 96 at the cemetery in Mannersdorf am Leithagebirge, where an adult female was buried. The belt has a belt hook with a leaf-shaped body which is the most common type with this kind of belts (Ramsl 2011, fig. 44; pl. 105: 4). This complex of burials is well dated to the end of stage LTC1 by a bronze fibula with a figureof-8 decoration on the strapped foot of BF-H3-A type (Bujna 2003, 60 f., fig. 28: A) and a blue glass ring decorated with tripple nipples of group 14 (Bujna 2005, 137 f., fig. 110).

The adult female buried in grave 96 at the cemetery in Mannersdorf am Leithagebirge has a specific costume garniture characterized by one or two armlets made of iron and/or glass worn on the left arm, an iron chain belt and absence of anklets. An analogous costume garniture is documented from female inhumation grave 2/1958 at the La Tène cemetery of Nitriansky Hrádok-Zámeček in southwestern Slovakia (Březinová 2011, 260 f., fig. 2: 1; pl. 2). The studied burial complex also belongs to the final phase of stage LT C1 - based on the bronze fibula with a false spring decoration on the strapped foot of BF-H3-c type (Bujna 2003, 60 f., fig. 28: C) and the glass ring of group 8b (Bujna 2005, 135 f., fig. 108). As for grave 9 at the cemetery of Nitra-Mlynárce, we probably deal with a similar female costume garniture characterized by absence of anklets, by an iron chain belt and an iron armlet.

Gold personal ornaments are rather rare finds in graves on the flat cemeteries from the La Tène period. Mostly they are represented by finger-rings made of precious metals. ${ }^{5}$ At the territory of southwestern Slovakia, gold finger-rings occurred in five La Tène graves - three female burials, one male burial and one child burial (Tab. 1). The above mentioned burial complexes with gold finger-rings chronologically belong to stage LTB1. ${ }^{6}$ Five graves with gold jewels (finger-ring, bracelet) from the cemetery in Mannersdorf am Leithagebirge can be dated to stage LTB1 as well (Ramsl 2011, 237, 238; graves 10/17 - LTB1b, 13/20a, 13/20b - LTB1a, 22/3b - LTB1b, 86/1, 86/2 - LTB1b, 115/7 and 115/8 - LTB1c).

Grave 9 from the cemetery in Nitra-Mlynárce is the only burial complex from the territory of Slovakia with gold ornament from stage LTC1. The gold spirals apparently decorated a sheet/burial shroud, in which the bodies of buried woman and child were wrapped.

5 Finger-rings made of precious metals at La Tène cemeteries on the territory from the Swiss Plateau to the Carpathian Basin were processed by J. Waldhauser (1998). He collected 75 exemplars from 38 sites in that area. He mentions only one gold ring from Czech Republic - from female grave VII/67 at the cemetery in Hostomice (Waldhauser 1998, 118).

6 Finds of saddle-shaped finger-rings from the territory of the Carpathian Basin were most recently processed by A. Rustoiu (2016).

7 The mention of the scarf lined with gold that covered the burnt bones in the secondary chamber grave in the tumulus at Kleinaspergle in Baden-Württemberg is presented by Oscar Fraas, who excavated the chamber in 1879 (cited by Kimmig 1988, fig. 13). 
Tab. 2. Burials of adults with little children at La Tène cemeteries from the territory of southwestern Slovakia and from the cemeteries Ludas-Varjú-dülő (Hungary) and Mannersdorf am Leithagebirge (Lower Austria). F - Woman; M - Man; Inf. - Child; Inh. - Inhumation; Crem. - Cremation.

\begin{tabular}{|l|c|c|c|c|c|c|l|}
\hline \multicolumn{1}{|c|}{ Cemetery } & Grave & Inh. & Crem. & Gender/Age & Chain belt Type & Dating LT & \multicolumn{1}{c|}{ Literature } \\
\hline Bajč-Vlkanovo & 14 & $\bullet$ & - & M(?) + inf.(?) & Gk-D-B & C1 & Benadik 1960, 398. \\
Malé Kosihy & 217 & - & - & $\mathrm{F}+$ inf. 1-2 & - & C1c & Bujna 1995, 53 n.; Jakab 1995, 192. \\
Maňa & 129 & - & - & F juv. + inf. 1-2 & - & B2c & Benadik 1983, 60; Dacík 1983, 160. \\
Nitra-Mlynárce & 9 & - & - & F ad. + inf.I & Gk-D-B & C1b & - \\
\hline Ludas - Varjú-dülö (H) & 699 & - & - & $\mathrm{F}+$ inf. 1 & - & C1a-b & É. Tankó/K. Tankó 2012, 200, 201. \\
Ludas - Varjú-dülö (H) & 1267 & - & - & F + inf. 1 & - & B2? & É. Tankó/K. Tankó 2012, 200, 201. \\
Mannersdorf am \\
Leithagebirge (NÖ)
\end{tabular}

\section{PALAEODEMOGRAPHIC PROFILE}

Burials of adults with little children are very rare at La Tène cemeteries (Tab. 2). Graves of children under 14 , i. e. Infans $0-2$, are not very numerous either. The share of children's burials at La Tène cemeteries with higher numbers of uncovered graves, i. e. with a statistically significant value, varies between 6 and $13 \%$.

There are several limiting factors to this phenomenon. Most young children - with regard to the ascribed status - were probably buried outside the cemetery. According to the anthropological analysis of 31 juveniles from the La Tène settlement and two related cemeteries with 170 inhumations at the site of Basel-Gasfabrik in Switzerland, most children died before they reached the age of 4 (Rissanen et al. $2013,140)$. Another objective limiting factor is the cremation burial rite which is documented at approx. one third of the 1050 La Tène graves known from the territory of Slovakia (Repka 2014, 33). For instance, up to $60 \%$ of the 102 uncovered graves at the La Tène cemetery at the Malé Kosihy site in southwestern Slovakia were of the cremation burial rite (Bujna 1995, 12). From the total number of uncovered graves, only 77 enabled anthropological identification of gender and/or age (Jakab 1995). The quality of the excavation technique and mainly the deficit of anthropological analysed can also be included among the subjective factors. Only $40 \%$ of the total number of La Tène burials uncovered in Slovakia have been anthropologically analyzed.

In this context, palaeodemographic profiles elaborated for some La Tène sites are helpful. From the settlement including ritual activity of the Celtic Galatians in the town of Gordion in Turkey, 47 individuals were anthropologically analyzed, including 21 from the Later Hellenistic Period (late $3^{\text {rd }}$ to $2^{\text {nd }}$ centuries BC) and 26 from the Roman Period ( $1^{\text {st }}$ to $2^{\text {nd }}$ centuries AD). Only $5 \%$ of children and up to $52 \%$ of young or middle aged adult females were identified in the Late Hellenistic Galatian group, however, in the Roman group, there were up to $27 \%$ of children and only $35 \%$ of young or middle aged adult females (Selinsky 2015). The highest mortality is observed among women of young or middle age (adultus I-II) also at the La Tène cemetery of Brežice-Sejmišče in Slovenia (Hincak/Guštin 2011, 244, fig. 1). From the 77 anthropologically analyzed La Tène graves from Malé Kosihy, 29 individuals were identified as females, including 7 young or middle aged adults, which makes $24 \%$ (Jakab 1995). Nevertheless, if we add half of the widely identified group of adultus to maturus to this value, i. e. 6 more individuals, we come to $48 \%$. To sum up, we can say that the highest mortality was seen among females of young or middle age (15-39 years of age), i. e. in the childbirth age - up to $50 \%$ in total.

\section{CONCLUSION}

The female grave 9 from the La Tène cemetery in Nitra-Mlynárce can be characterized by several specific attributes. Orientation of the buried female with her head to the east is very rare at La Tène cemeteries from the territory of southwestern Slovakia. The mode of depositing of the dead woman's remains in a flaxed ("hocker") position on her right side is also very unique with regard to the burial rite of the 
Celtic population in the territory of southwestern Slovakia; it could be associated with the toddler in her arms. The combination of ornaments and items of costume including a chain belt, an armlet and absence of anklets represent a specific costume garniture in stage LTC1 in the Celtic environment of southwestern Slovakia. Unlike the Celtic environment in Moravia and Czechia, anklets still occur among female grave goods in Slovakia in stage LT C1 (Bujna 2005, 158). Gold wire spirals decorating a winding-sheet or shroud, in which the bodies of buried woman and child were wrapped, are a specific and unique ornamental fittings in stage LTC1 in the Celtic environment not only in southwestern Slovakia. And, finally, probably the most bizarre part of grave goods - a chain of 23 hooked cramp irons. However, they are not part of the grave construction. The chain was probably supposed to symbolize the kinship of the mother and the child and express the fate of the deceased woman.

We can also consider other possible explanations of the meaning of the buried female's tied body. At the cemetery in Casalecchio di Reno in the north of Italy dated to the 4th century BC and attributed to the Boii, skeletons with dark bands were uncovered. The bands could be remains of ropes tying the dead bodies (Cesari/Neri 2010, 52-54; cited by Braccini 2014, 236, note 17). Tying - according to T. Braccini (2014, 236, note 17) - symbolized death.

In literature, we can also come across interpretation of the ropes as anti-revenant measures (see to it Bujna 2014, 455 f.). T. Braccini, who deals with anomalous burials in the light of archaeological investigations in one chapter of his publication on "vampire archaeology", is skeptical to such interpretation after assessment of multiple find contexts.

The determining factors of this unique burial at the cemetery in Nitra-Mlynárce might have included a specific social status of the buried woman in the community, or her foreign origin and - the last, but not least - the circumstances of her death.

Translated by Mgr. Viera Tejbusová

\section{BIBLIOGRAPHY}

Benadik 1960

Benadik 1975

Benadik 1983

Benadik/Vlček/Ambros 1957

Braccini 2014

Březinová 1999

Březinová 2011

Bujna 1989

Bujna 1992

Bujna 1995

Bujna 2003

Bujna 2005

Bujna 2011

Bujna 2014

Bujna/Kováčová 1988 Bujna/Štefanka 2001
B. Benadik: Keltské pohrebisko v Bajči-Vlkanove. Slovenská archeológia 8, 1960, 393-451.

B. Benadik: Besonders angelegte Gräber auf keltischen Gräberfeldern der Slowakei und ihre gesellschaftliche Bedeutung. Ausgrabung des Gräberfeldes in Palárikovo und sein Charakter. Alba Regia 14, 1975, 97-106.

B. Benadik: Maňa. Keltisches Gräberfeld. Fundkatalog. Nitra1983.

B. Benadik/E. Vlček/C. Ambros: Keltské pohrebiská na juhozápadnom Slovensku - Keltische Gräberfelder der Südwestslowakei. Bratislava 1957.

T. Braccini: Před Draculou. Archeologie upíra. Argo 2014. (Prima di Dracula. Archeologia del vampiro. 2011. Preklad T. Sieglová).

G. Březinová: Sídlisko z doby laténskej v Nitre-Šindolke a jeho postavenie v rámci regiónu stredného Ponitria. Slovenská archeológia 47, 1999, 61-74.

G. Březinová: The Biritual Cemetery at Šurany-Nitriansky Hrádok, District of Nové Zámky, Slovakia. In: S. Berecki (ed.): Iron Age Rites and Rituals in the Carpathian Basin. Proceedings of the international Colloquium from Târgu Mureş, 7. -9. October 2011. Târgu Mureş 2012, 259-271.

J. Bujna: Das latènezeitliche Gräberfeld bei Dubník. I. Slovenská archeológia 37, 1989, 245-354.

J. Bujna: Nitra-Mlynárce. Výskumná správa 13 046/92. Dokumentácia AÚ SAV v Nitre. Nitra 1992. Unpublished.

J. Bujna: Malé Kosihy - latènezeitliches Gräberfeld. Nitra 1995.

J. Bujna: Spony z keltských hrobov bez výzbroje z územia Slovenska (typovo-chronologické triedenie LTB a LTC1 spôn). Slovenská archeológia 51, 2003, 39-108.

J. Bujna: Kruhový šperk z laténskych ženských hrobov na Slovensku. Nitra 2005.

J. Bujna: Opasky ženského odevu z doby laténskej. Nitra 2011.

J. Bujna: Deviantný pohreb na keltskom pohrebisku v Palárikove. Prípadová štúdia nenormatívnych pohrebných praktík. In: J. Čižmářová/N. Venclová/G. Březinová (eds.): Moravské křižovatky. Střední Podunají mezi pravěkem a historií. Brno 2014 , 449-460. J. Bujna/A. Kováčová: Laténsky hrob z Nitry. AVANS 1987, 1988, 38, 39.

J. Bujna/P. Štefanka: Ojedinelý nález článku stredolaténskeho rełazového opasku z Nitry. AVANS 2000, 2001, 49-51. 
Cesari/Neri 2010

Dacík 1983

Eisner 1933

Hincak/Guštin 2011

Chropovský 1958

Chropovský 1986

Chropovský/Kováčová/Csásta 1989

Jakab 1995

Jakab/Vondráková 1989

Kimmig 1988

Lichardus 1964

Paulík/Novotná/Benadik 1962

Pieta 1993

Ramsl 2011

Repka 2014

Rissanen et al. 2013

Rustoiu 2008

Rustoiu 2016

Selinsky 2015

Tankó/Tankó 2012

Vlček 1957

Waldhauser 1998
L. Cesari/D. Neri: Sepolture anomale. Indagini archeologiche e antropologiche dall'epoca classica al Medioevo in Emilia Romagna. Guida alla mostra. Castelfranco Emilia 2010.

T. Dacík: Anthropologische Analyse der Skelette aus dem keltischen Gräberfeld in Maňa. In: Benadik 1983, 149-167.

J. Eisner: Slovensko v pravěku. Bratislava 1933.

Z. Hincak/M. Guštin: Anthropological analysis of Celtic graves from Brežice and Dobova (Slovenia). In: M. Guštin/M. Jevtić (eds.): The Eastern Celts: the communities between the Alps and the Black Sea. Koper - Beograd 2011, 241-254.

B. Chropovský: Laténske pohrebisko v Nebojsi, okr. Galanta. Slovenská archeológia 6, 1958, 120-130.

B. Chropovský: Nitra-Martinský vrch. Výskumná správa 11 634/86. Dokumentácia AÚ SAV v Nitre. Nitra 1986. Unpublished.

B. Chropovský/A. Kováčová/J. Csásta: Nitra stavba SPTŠ. Výskumná správa 12 0352/89. Dokumentácia AÚ SAV v Nitre. Nitra 1989. Unpublished.

J. Jakab: Anthropologische Grundanalyse des birituellen latènezeitlichen Gräberfeldes in Malé Kosihy. In: Bujna 1995, 183-210.

J. Jakab/M. Vondráková: Ergebnisse der anthropologischen Analyse des latènezeitlichen Gräberfeldes in Dubník. Slovenská archeológia 37, 1989, 355-370.

W. Kimmig: Das Kleinaspergle. Studien zu einem Fürstengrabhügel der frühen Latènezeit bei Stuttgart. Forschungen und Berichte für Vor- und Frühgeschichte in Baden-Württemberg 30. Stuttgart 1988.

J. Lichardus: Nitra VŠP. Výskumná správa 6 969/64. Dokumentácia AÚ SAV v Nitre. Nitra 1964. Unpublished.

J. Paulík/M. Novotná/B. Benadik: Život a umenie doby železnej na Slovensku. Malá výtvarná knižnica. Zväzok 11. Bratislava 1962.

K. Pieta: Stredolaténske zvieracie žiarové hroby alebo doklady kultových praktík z Nitry? Slovenská archeológia 41, 1993, 41-58.

P. C. Ramsl: Das latènezeitliche Gräberfeld von Mannersdorf am Leithagebirge, Flur Reinthal Süd, Niederösterreich. H. Friesinger (Hrsg.): Mitteilungen der Prähistorischen Kommission Band 74. Wien 2011.

D. Repka: Pohrebiská z doby laténskej na Slovensku. Študijné zvesti AÚ SAV 56, 2014, 23-54.

H. Rissanen/S. Pichler/N. Spichtig/K. W. Alt/D. Brönnimann/C. Knipper/M. Kühn/P. Rentzel/B. Röder/J. Schibler/B. Stopp/W. Vach/O. Warnberg/G. Lassau: „Wenn Kinder sterben..." - Säuglinge und Kleinkinder vom latènezeitlichen Fundplatz Basel-Gasfabrik (Kanton Basel-Stadt, Schweiz). In: S. Wefers/J. E. Fries/J. FriesKnoblach/C. Later/U. Rambuschek/P. Trebsche/J. Wiethold (Hrsg.): Eisenzeit und Geschlechterforschung. Bilder - Räume - Rollen. Beiträge zur gemeinsamen Sitzung der AG Eisenzeit und der AG Geschlechterforschung während des 7. Deutschen Archäologiekongresses in Bremen 2011. Beiträge zur Ur-und Frühgeschichte Mitteleuropas 72. Langenweißbach 2013, 127-142.

A. Rustoiu: Războinici și societate în aria celtică transilvăneană: studii pemarginea mormântului ci coif de la Çiumești (Warrors and society in Celtic Transylvania: studies on the grave with helmet from Çiumești). Interferențe etnice și culturale în milenille I a. Chr. I p. Chr. (Ethnic and cultural interferences in th $1^{\text {st }}$ millenium B.C. To the $1^{\text {st }}$ millenium A.D.). Vol. 13. Cluj - Napoca 2008.

A. Rustoiu: Lords and ladies of the rings. Saddle-shaped fingerrings from the Carpathian Basin. Archeologické rozhledy 68, 2016, 333-362.

P. Selinsky: Celtic Ritual Activity at Gordion, Turkey: Evidence from Mortuary Contexts and Skeletal Analysis. International Journal of Osteoarchaeology 26, 2015, $213-225$

É. Tankó/K. Tankó: Cremation and Deposition in the Late Iron Age Cemetery at Ludas. In: S. Berecki (ed.): Iron Age Rites and Rituals in the Carpathian Basin. Proceedings of the International Colloquium from Târgu Mureş. Cluj - Napoca 2012, 249-258. E. Vlček: Antropológia Keltov na juhozápadnom Slovensku - Anthropologie der Kelten in der südwestlichen Slowakei. In: Benadik/Vlček/Ambros 1957, 203-289.

J. Waldhauser: Die Goldfingerringe von Münsingen-Rain und ihre Vergleichsstücke aus Flachgräberfeldern im Gebiet zwischen dem schweizerischen Mittelland und dem Karpatenbecken. In: F. Müller (ed.): Münsingen-Rain, ein Markstein der keltischen Archäologie. Funde, Befunde und Methoden im Vergleich. Akten Internationales Kolloquium „Das keltische Gräberfeld von Münsingen-Rain 1906-1996" 9.-12. Oktober 1996. Bern 1998, 85-121. 


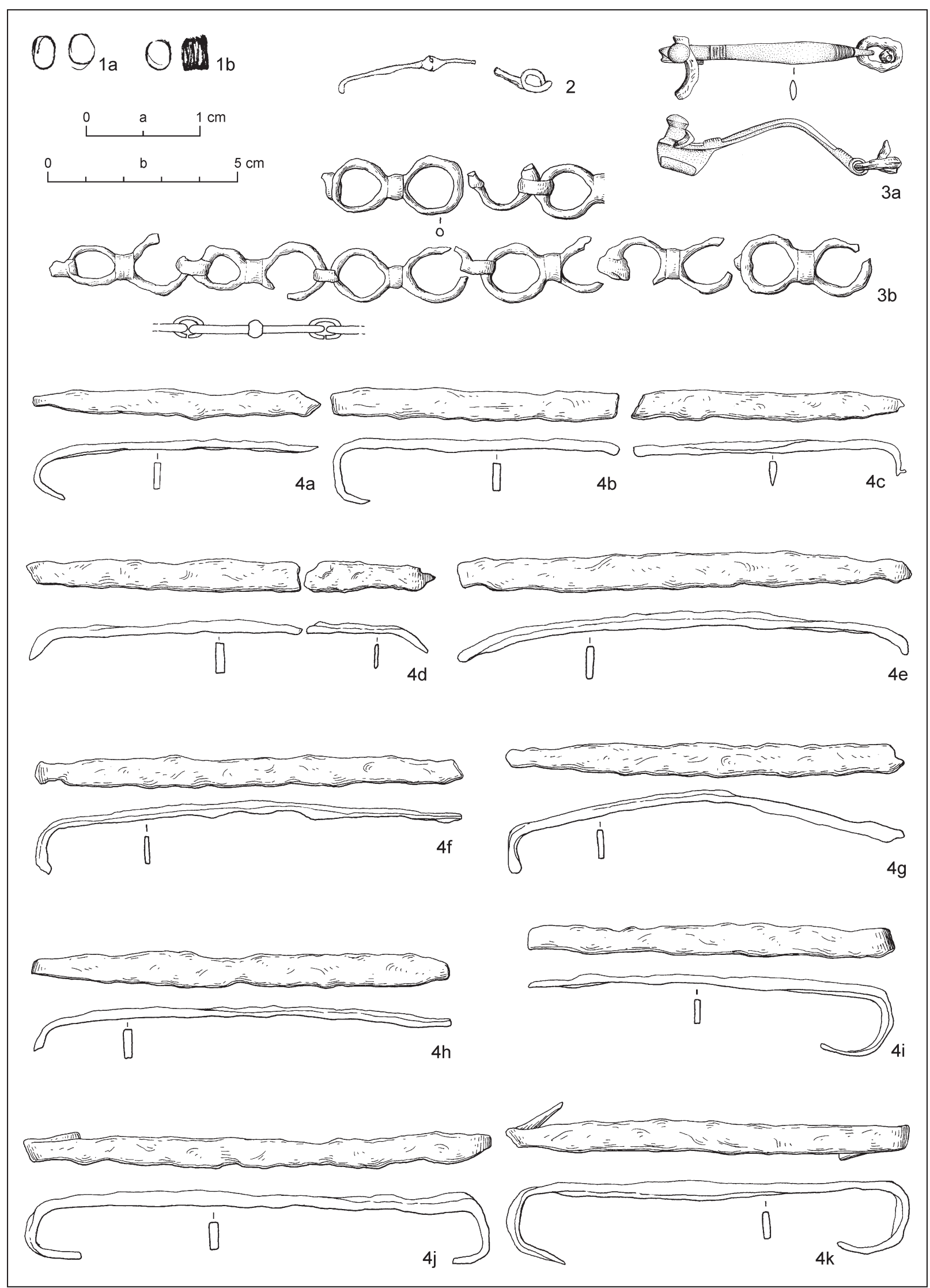

Pl. I. Nitra-Mlynárce, grave 9, context A - part 1.1 - gold; 3a-bronze; other iron. Scale: a - 1; b-2-4. 


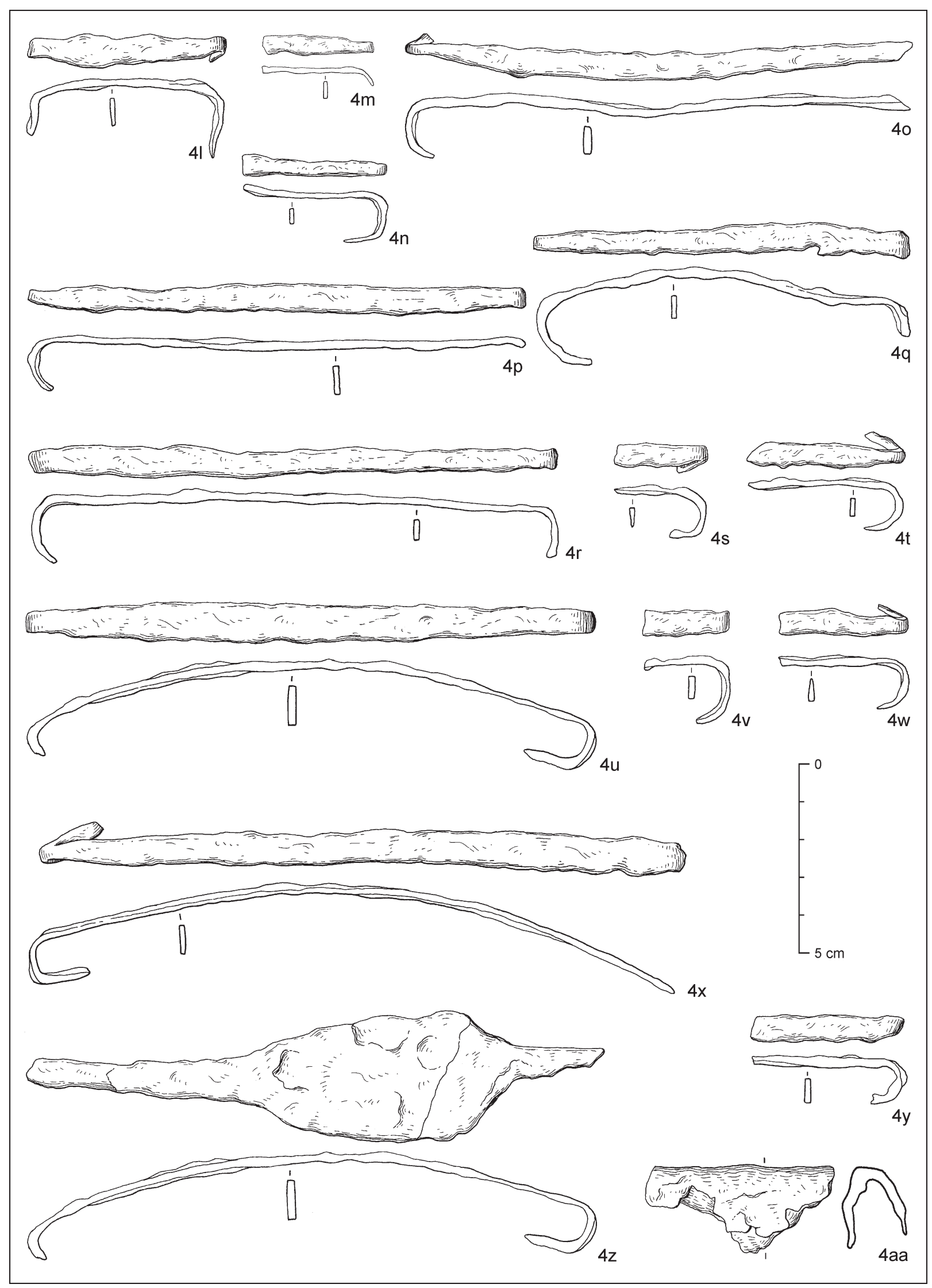

Pl. II. Nitra-Mlynárce, grave 9, context A - part 2. All the iron. 


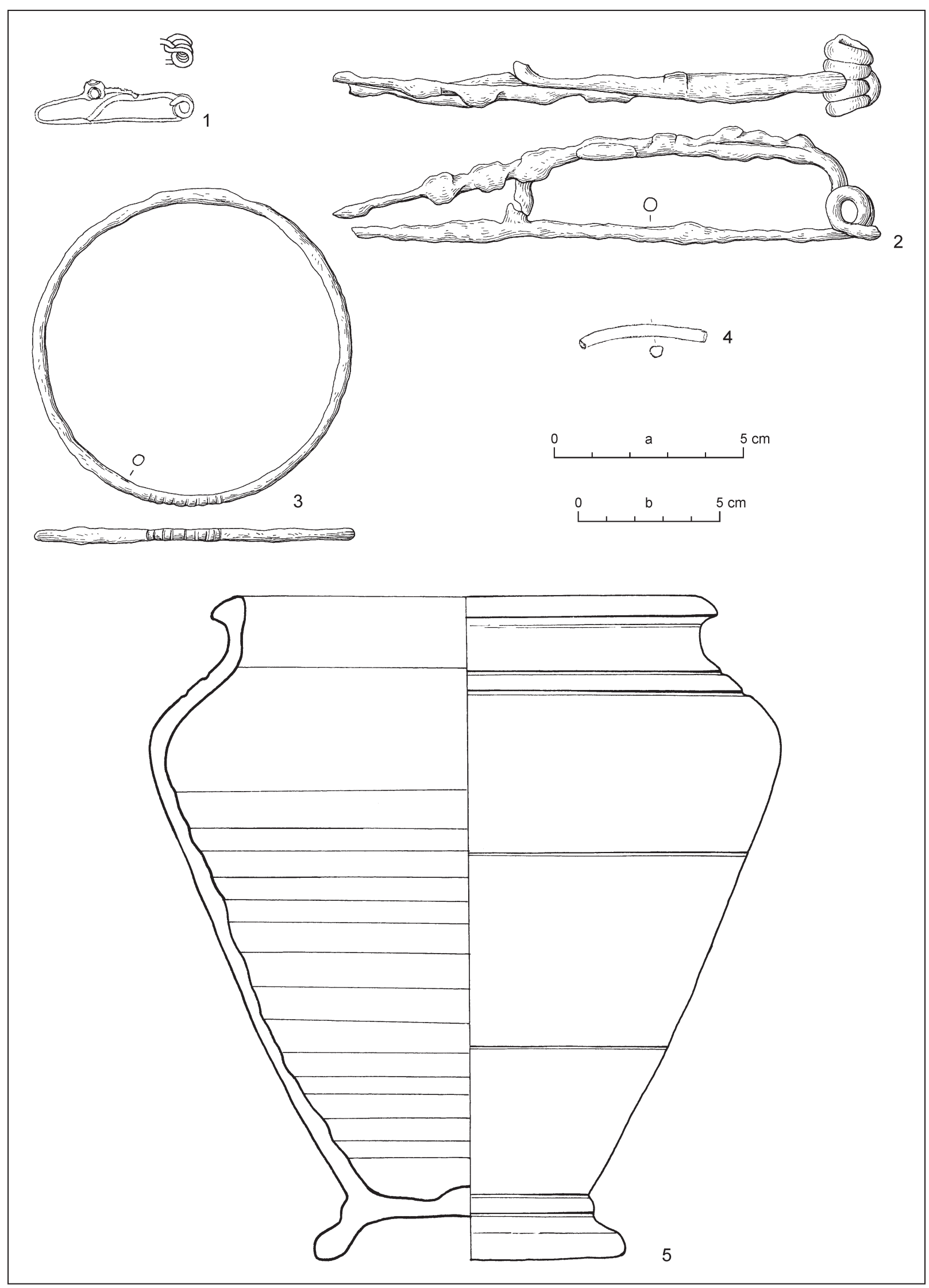

Pl. III. Nitra-Mlynárce, grave 9, context B. 1, 4 - bronze; 2, 3 - iron. Scale: a - 1-4; b-5. 


\title{
„Spútaná svojím osudom" - hrob ženy s dojčatom na keltskom pohrebisku v Nitre-Mlynárciach
}

\author{
Jozef Bujna
}

Súhrn

Z územia mesta Nitry (plocha asi $100 \mathrm{~km}^{2}$ ) je známych sedem polôh s hrobovými nálezmi z doby laténskej, jedna d’alšia je otázna a deviata poloha je $\mathrm{v}$ tesnej blízkosti územia mesta (obr. 1). Sumárne ide približne o 30 hrobov. Pohrebisko s predmetným hrobom ženy pochovanej s dojčatom sa nachádza v mestskej časti Mlynárce, na nízkej terase pravého brehu rieky Nitra. Na ploche približne 50 x 150 m bolo záchranným výskumom v roku 1972, počas stavby cestného nadjazdu, odkrytých 90 hrobov lužickej kultúry, medzi ktorými sa vyskytlo tiež 11 hrobov z doby laténskej. Z tohto počtu bolo 10 hrobov s kremáciou a iba jeden s inhumáciou. V kostrovom hrobe 9 bola pochovaná žena vo veku približne 35-40 rokov so 7-8 mesačným dietatom. Kontext je označený ako 9A.

Tvar a rozmery hrobovej jamy neboli záchranným výskumom počas zemných prác pri stavbe nadjazdu zachytené. Telo ženy, uložené na pravom boku v mierne pokrčenej polohe a orientované v smere približne východ (hlava) západ, bolo odkryté v híbke $90 \mathrm{~cm}$. V náručí ženy bolo uložené dojča. Detská kostrička bola silne strávená (obr. 2; 3). V priestore tela ženy a diet’ata boli nájdené viaceré zlaté drôtené špirálky (tab. I: 1a, b), na hrudníku ženy železná spona (tab. I: 2), okolo pásu železný retazový opasok z osmičkovitých článkov stiahnutých svorkou a spojených krúžkami s bronzovou sponou typu Certosa, sekundárne použitou ako zápona (tab. I: 3a, b) a pod trupom a pozdĺž chrbtu retaz z 23 kusov navzájom zahákovaných železných skôb (tab. I: 4a-k; II).

Asi $40 \mathrm{~cm}$ západne od chodidiel ženy, v híbke $80-90 \mathrm{~cm}$, boli odkryté kosti z lebky svine a pod nimi nádoba (obr. 4; tab. III: 5). V tesnej blízkosti nádoby bronzová spona (tab. III: 1), železná spona (tab. III: 2), železný tyčinkový kruh (tab. III: 3) a fragment bronzovej tyčinky (tab. III: 4). Kontext bol označený ako 9B.

Priestorový vztah kontextov 9A a 9B vzhladom na absenciu ich pôdorysného vymedzenia nemožno jednoznačne definovat'. Ked’že v priestore kontextu 9B neboli nájdenékosti d’alšiehol'udskéhojedinca a podl’a relatívne chronologického zaradenia oba kontexty boli zrejme súveké, LT C1b-c, a napokon tiež podla krátkej vzájomnej vzdialenosti tvorili oba kontexty pravdepodobne jeden celok, teda jeden hrob.

Pohreby dospelých s malými det’mi sú na laténskych pohrebiskách zastúpené iba vo vel’mi nízkom počte (tabela 2). Nízkym počtom sú doložené tiež hroby detí vo veku do 14 rokov, t. j. Infans 0-2. Podiel detských pohrebov na laténskych pohrebiskách s vyšším počtom odkrytých hrobov, teda so štatisticky preukaznou hodnotou, sa pohybuje medzi 6-13\%. Väčšina detí nízkeho veku vzhl’adom na vrodený status nebola zrejme pochovaná na pohrebisku. Podla antropologickej analýzy 31 nedospelých jedincov z laténskeho sídliska a k nemu prislúchajúcich dvoch pohrebísk so 170 kostrovými hrobmi na lokalite Basel-Gasfabrik vo Švajčiarsku väčšina detí zomrela skôr, než dosiahla štyri roky života (Rissanen et al. 2013, 140).

$\mathrm{V}$ tomto kontexte sú prínosné paleodemografické profily vypracované pre niektoré lokality z doby laténskej. Zo sídliska a pohrebiska keltských Galatov v meste Gordion v Turecku bolo antropologicky analyzovaných 47 indivíduí, z toho 21 z neskorého helenistického obdobia (neskoré 3. -2. stor. pred Kr.) a 26 z doby rímskej (1.-2. stor. po Kr.). V rámci neskorohelenistickej galatskej skupiny bolo identifikovaných iba $5 \%$ detí a až $52 \%$ žien vo veku juvenis až adultus, avšak v rímskej skupine až $27 \%$ detí a iba $35 \%$ žien vo veku juvenis až adultus (Selinsky 2015). Najvyššie percento úmrtnosti vykazujú ženy vo veku adultus I až II tiež na keltskom pohrebisku z lokality Brežice-Sejmišče v Slovinsku (Hincak/Guštin 2011, 244, obr. 1). Zo 77 antropologicky analyzovaných hrobov z laténskeho pohrebiska Malé Kosihy bolo 29 jedincov určených ako žena, z toho sedem vo veku juvenis až adultus, čo je 24 \% (Jakab 1995). Ak však k tejto hodnote pridáme polovicu zo širšie určenej skupiny adultus až maturus, teda d’alších šest’ jedincov, dostávame hodnotu až 48 \%. Sumarizujúc možno konštatovat', že úmrtnost’ bola najvyššia u žien vo veku juvenis až adultus (15-39 rokov), teda vo veku plodnosti, celkovo až $50 \%$.

Ženský hrob 9 z laténskeho pohrebiska Nitra-Mlynárce možno charakterizovat viacerými špecifickými atribútmi. Orientácia pochovanej ženy hlavou na východ je na keltských pohrebiskách z územia juhozápadného Slovenska velmi ojedinelá. Osobitou v rámci pohrebných zvyklostí u keltskej populácie z územia juhozápadného Slovenska sa javí tiež spôsob uloženia telesných pozostatkov zomrelej ženy v mierne pokrčenej polohe na pravom boku, čo možno dávat do súvisu s dojčencom v jej náručí. Kombinácia ozdôb a súčastí odevu v zložení retazový opasok, náramenica, absencia nánožných kruhov predstavuje v stupni LTC1 v keltskom prostredí juhozápadného Slovenska osobitú krojovú garnitúru. Na rozdiel od keltského prostredia na území Moravy a Čiech, na juhozápadnom Slovensku sa totiž aj v stupni LTC1 nad’alej vyskytujú vo výbave ženských hrobov nánožné kruhy. Špirálky zo zlatého drôtu, zdobiace plachtu či pohrebný rubáš, do ktorého boli zabalené telá pochovanej ženy a malého dietata, predstavujú v stupni LTC1 v keltskom prostredí nielen na juhozápadnom Slovensku taktiež osobitú a unikátnu ozdobu. Spolu s ostatnou krojovou garnitúrou indikujú vyšší sociálny status pochovanej. A napokon azda najbizarnejší prídavok v hrobovej výbave ret’az z 23 kusov navzájom zahákovaných železných skôb. Tieto však nesúvisia s konštrukčnou úpravou hrobovej jamy 
či pohrebnej schránky. Retaz mala zrejme predstavovat’ symbolické puto medzi matkou a jej dietatom a poukazovat’ na fatálny osud pochovanej.

Do úvahy prichádzajú tiež d’alšie možnosti vysvetlenia významu spútania pochovanej ženy. Na pohrebisku v Casalecchiu di Reno v severnom Taliansku, datovanom do 4. stor. pred Kr. a pripisovanom Bójom, boli odkryté kostry s tmavými pásmi, ktoré by mohli predstavovat’ zvyšky povrazov, ktorými boli mŕtvoly zviazané. Zviazanie malo podla T. Bracciniho (2014, 236, pozn. 17) symbolizovat' smrt'.

V literatúre sa môžeme stretnút tiež s interpretáciou, že ide o protirevenantné opatrenia. T. Braccini (2014), ktorý sa anomálnymi pohrebmi vo svetle archeologických výskumov zaoberá v jednej kapitole jeho knižnej publikácie o „,archeológii upíra“, sa však po vyhodnotení viacerých nálezových kontextov k takejto interpretácii stavia skepticky.

Determinujúcimi faktormi tohto osobitého hrobu z pohrebiska v Nitre-Mlynárciach mohli byt špecifický sociálny status, ktorý pochovaná žena v danej komunite zastávala, azda jej nedomáci pôvod a v neposlednom rade okolnosti smrti.

Obr. 1. Lokality s hrobovými nálezmi z doby laténskej na území mesta Nitra. 1 - Nitra-Mlynárce (Bujna 1992); 2 - Nitra, Štúrova ulica, Krajský súd, predtým Námestie 1. mája (Paulík/Novotná/Benadik 1962, 320, obr. 58; Pieta 1993); 3 - Nitra, Slovenská polnohospodárska univerzita - SPU, predtým Vysoká škola polnohospodárska - VŠP (Lichardus 1964); 4 - Nitra-Chrenová II (Pieta 1993, obr. 8: 2, 3); 5 - Nitra-Mikov dvor (Bujna/Kováčová 1988); 6 - Nitra-Zobor, Martinský vrch (Chropovský 1986); 7 - Nitra-Zobor, Šindolka (Chropovský/Kováčová/Csásta 1989); 8. Nitra - Hypermarket Tesco (?; Bujna/Štefanka 2001); 9 - Lužianky (Eisner 1933, 170-176).

Obr. 2. Nitra-Mlynárce, hrob 9. 1 - kontext 9A; 2 - kontext 9B. Foto archív AÚ SAV.

Obr. 3. Nitra-Mlynárce, hrob 9, kontexty 9A a 9B.

Obr. 4. Nitra-Mlynárce, hrob 9, kontext B. Nádoba. Foto archív AÚ SAV.

Tab. I. Nitra-Mlynárce, hrob 9, kontext A - čast' 1. 1 - zlato; 3a - bronz; ostatné železo. Mierka: a - 1; b - 2-4.

Tab. II. Nitra-Mlynárce, hrob 9, kontext A - čast’ 2. Všetko železo.

Tab. III. Nitra-Mlynárce, hrob 9, kontext B. 1, 4-bronz; 2, 3 - železo. Mierka: a - 1-4; b- 5 .

Tabela 1. Laténske hroby so zlatým šperkom vo výbave z územia Slovenska a z pohrebiska Mannersdorf am Leithagebirge (Dolné Rakúsko). F - žena; M - muž; Inf. - diet’a. Mannersdorf am Leithagebirge: hrob 10/17 - LTB1b; 13/20a, 13/20b - LTB1a; 22/3b - LTB1b; 86/1, 86/2 - LTB1b; 115/7, 115/8 - LTB1c (Ramsl 2011, 237, 238).

Tabela 2. Pohreby dospelých s malými det’mi na laténskych pohrebiskách z územia juhozápadného Slovenska a z pohrebísk Ludas-Varjú-dűlő (Mad’arsko) a Mannersdorf am Leithagebirge (Dolné Rakúsko). F - žena; M - muž; Inf. - dieta; Inh. - inhumácia; Crem. - kremácia.

prof. Jozef Bujna, CSc.

Filozofická fakulta UKF v Nitre

Katedra archeológie

Hodžova 1

SK - 94974 Nitra

jbujna@ukf.sk 
